\title{
Kajian Morfologi, Sitologi, dan Struktur Anatomi Daun Nepenthes spp. asal Kalimantan Barat
}

\author{
FITRI DAMAYANTI ${ }^{1}$, IKA ROOSTIKA ${ }^{2}$, MUHAMMAD MANSUR ${ }^{3}$ \\ ${ }^{1}$ Jurusan Pendidikan Biologi F. TMIPA Universitas Indraprasta, Jalan Nangka No. 58 Jagakarsa Jakarta Selatan \\ ${ }^{2}$ Balai Besar Penelitian dan Pengembangan Bioteknologi dan Sumberdaya Genetik Pertanian, Jalan Tentara Pelajar 3A Bogor 16111 \\ ${ }^{3}$ PUSLIT Biologi LIPI Jl. Raya Bogor Km. 46 Cibinong \\ *email: fitridamayantineng@gmail.com
}

Manuscript received: 15 Mei 2015 Revision accepted: 29 Juli 2015

\begin{abstract}
The objective was to describe morphology, structure of anatomy, and cytology characters of the five species as well as to determine their differences each other. In the present study five Nepenthes from West Kalimantan were evaluated: $N$. veitchii, $N$. negleta, $N$. bicalcarata, $N$. clipeata, and N. hirsuta. Morfology analysis of five species Nepenthes showed different morphology in particular shape of pitcher that each species have a unique pitcher. Cytology analysis showed high variation between species. In general, it was demonstrated that $N$. bicalcarata tended to have bigger epidermal cells and stomata. $N$. bicalcarata had aktinocytik tipe of stomata and N. clipeata, N. veitchii, N. hirsuta, and N. negleta had anomocytik tipe of stomata. Stomata only had on the lower surface except $N$. negleta had stomata on the upper too. $N$. negleta had the higher of density and index stomata. The result of transversal showed variation of mesofil tissue (parenchim of palisade and spons). Epidermis cell was conducted in one layer with hipoepidermis cell more than one layer with the biggest size than epidermis cell. $N$. veitchii had more tricoma from the others species.
\end{abstract}

Keywords: Nepenthes spp., morfology, anatomy, cytology

\section{LATAR BELAKANG}

Kalimantan merupakan salah satu pusat penyebaran Nepenthes terbesar di dunia (Mansur, 2006). Tanaman ini memiliki kantong dengan bentuk dan warna yang unik. Namun Nepenthes merupakan salah satu tanaman dalam kategori langka dengan tingkat erosi genetik yang tinggi termasuk dalam CITES (Convention on International Trade of Endangered Spesies of Wild Flora and Fauna) terdapat dalam apendiks I dan II yang tergolong hampir punah dan langka. Tiga jenis Nepenthes merupakan spesies endemik Kalimantan Barat (N. bicalcarata, $N$. veitchii, dan $N$. clipeata) dengan populasi yang sangat terbatas (Mansur, $d k k$ 2009). Hal ini mendesak dilakukan kajian yang mendalam seputar tanaman Nepenthes termasuk aspek Biologi dalam hubungannya untuk pembudidayaan.

Informasi morfologi, anatomi, dan sitologi tanaman ini belum banyak yang mengkaji. Variasi morfologi, variasi struktur antomi, dan sitologi sangat menarik untuk diketahui. Secara morfologi, anatomi, dan sitologi terdapat karakter spesifik yang dapat digunakan sebagai pembeda antara spesies Nepenthes ditambah lagi tanaman ini memiliki jenis yang sangat beragam dan setiap daerah memiliki jenis Nepenthes yang khas.

Salah satu karakter dalam evaluasi keragaman yang mudah dievaluasi adalah ciri anatomi. Selain itu, ciri sitologi dilaporkan juga berkaitan erat dengan keragaman genetik. Ciri sitologi tersebut antara lain panjang stomata (Horak, 1972; Pryzywara et al., 1988; Hamill et al., 1992; Lozykowska, 2003; Beck et al., 2002), kerapatan stomata (Horak, 1972; Vandenhout et al., 1995; Beck et al., 2002), jumlah kloroplas pada sel penjaga stomata (Pryzywara et al., 1988; Lozykowska, 2003), dan ukuran sel epidermis (Griffiths et al., 1996).

Variasi pada morfologi, struktur anatomi, dan sitologi diharapkan dapat digunakan untuk membantu sistematika pada Nepenthes, selain itu karakterisasi anatomi dan sitologi merupakan salah satu aspek Biologi yang sangat berarti dalam program pemuliaan. Hasil penelitian ini diharapkan dapat memperkaya informasi tentang variasi morfologi, sitologi, dan struktur anatomi berbagai jenis Nepenthes sehingga dapat digunakan sebagai sumber informasi data untuk penelitian lainnya..

\section{METODE}

Penelitian dilakukan di Universitas Indraprasta PGRI, Jakarta dan Pusat Penelitian Biologi Lembaga Ilmu Pengetahuan Indonesia (PUSLIT Biologi-LIPI) pada bulan September-November 2009. Bahan tanaman yang digunakan dalam penelitian ini adalah lima spesies Nepenthes endemik Kalimantan Barat, yaitu N. veitchii, N. bicalcarata, $N$. clipeata, $N$. negleta, dan $N$. hirsuta. Pengamatan morfologi dilakukan terhadap morfologi daun, batang, kantong, dan pembungaan. Sediaan mikroskopis untuk pengamatan sitologi berupa sayatan membujur (paradermal) dan sayatan melintang (transversal) untuk pengamatan anatomi daun.

\section{Pembuatan Sayatan Paradermal}

Pembuatan sayatan paradermal menggunakan metode utuh (whole mount) (Sass, 1951). Daun difiksasi dalam alkohol $70 \%$ selama 15 menit kemudian direndam dalam larutan 
$\mathrm{HNO}_{3} 20 \%$ selama 3-4 jam agar lapisan epidermis dapat dengan mudah dilepaskan dari jaringan mesofil. Lapisan epidermis bawah daun diperoleh dengan bantuan pinset dan silet. Lapisan epidermis tersebut diletakkan pada gelas objek dan diwarnai dengan pewarna safranin $1 \%$ selama 5 menit, kemudian ditutup dengan gelas penutup. Preparat diamati di bawah mikroskop dengan perbesaran 400x. Karakter sitologi yang diamati adalah bentuk, kerapatan stomata, panjang dan lebar sel penjaga stomata, panjang dan lebar sel epidermis, luas serta indeks stomata. Data tersebut merupakan nilai rata-rata dari pengukuran lima bidang pandang yang dipilih secara acak masing-masing dengan lima ulangan.

\section{Pembuatan Sayatan Transversal}

Sayatan transversal dibuat mengikuti metode parafin (Sass, 1951). Daun Nepenthes dipotong dengan ukuran $0.5 \times 0.5 \mathrm{~cm}$ kemudian difiksasi dalam larutan FAA selama 24 jam. Dehidrasi dilakukan secara bertahap dengan larutan etanol 50\%:70\%:95\% dan etanol absolut. Penjernihan dilakukan juga secara bertahap menggunakan campuran larutan etanol dan xilol dengan perbandingan $3: 1 ; 1: 1 ; 1: 3$ dan xilol absolut. Masing-masing tahapan dehindrasi dan penjernihan berlangsung selama 3 jam. Pembuatan sayatan setebal $8 \mu \mathrm{m}$ dilakukan dengan menggunakan mikrotom putar, selanjutnya pita parafin direkatkan pada gelas objek yang telah diolesi arabic gum $5 \%$. Pewarnaan yang dilakukan adalah pewarnaan ganda menggunakan safranin $1 \%$ dan fast green $0.5 \%$. Preparat diamati di bawah mikroskop pada perbesaran 400x. Peubah yang diamati meliputi tebal helaian daun dan tebal jaringan palisade. Nilai peubah merupakan nilai rata-rata dari pengukuran lima bidang pandang yang dipilih secara acak masing-masing dengan lima ulangan.

\section{HASIL}

Kajian Morfologi Nepenthes spp.

Nepenthes adalah tumbuhan merambat (liana), berumah dua, serta jantan dan betina terpisah pada individu yang berbeda, bersifat terestrial dan epifit pada ranting atau pohon besar. Nepenthes adalah tanaman yang khas yaitu memiliki kantong dengan ukuran dan warna yang menarik dan unik. Kantong ini merupakan ujung daun yang berubah bentuk dan fungsi menjadi penangkap serangga atau binatang kecil lainnya sehingga tanaman ini disebut juga tanaman karnivora. Morfologi daun, batang, kantong dan pembungaan pada lima spesies Nepenthes asal Kalimantan Barat sangat bervariasi (Tabel 1).

Umumnya bangun daun Nepenthes adalah memanjang sampai lancet namun $N$. hirsuta dan $N$. veitcii memiliki bentuk bangun bulat sampai lonjong. Permukaan bawah daun umumnya ditumbuhi bulu-bulu halus (trikoma) demikian juga pada batang dan tunas mudanya. $N$. hirsuta memiliki trikoma tidak hanya dipermukaan bawah namun dipermukaan atas daun juga ditumbuhi trikoma. $N$. bicalcarata memiliki kantong yang besar dengan dua taring di bawah kantong penutup di mana ciri ini hanya dimiliki oleh spesies ini. $N$. clipeata memiliki kantong yang unik dengan bagian bawah kantong membulat dan bagian atas yang berbentuk corong, namun sayangnya spesies ini sudah sangat langka. N. hirsuta memiliki penutup kantong yang berbentuk jantung. N. veitchii memiliki kantong yang berukuran besar dengan leher yang berkerah lebar dan mampu melilit pada pohon besar .

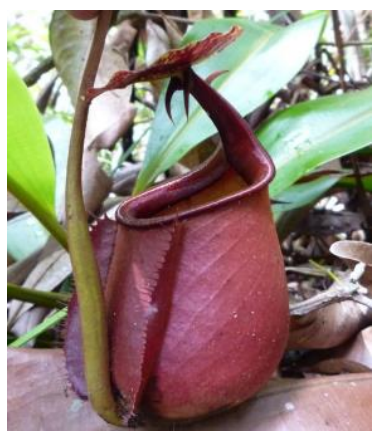

N. bicalcarata

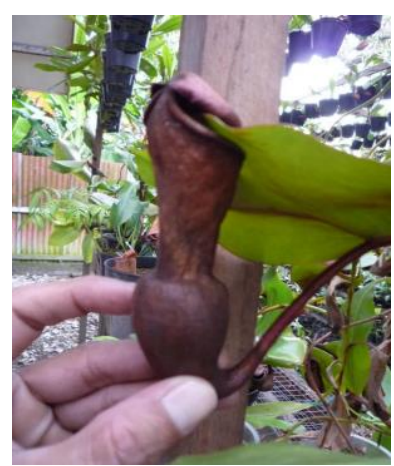

N. clipeata

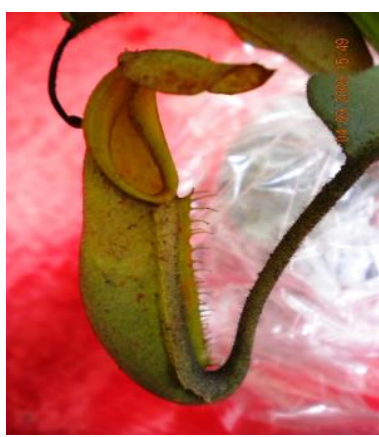

N. veitchii

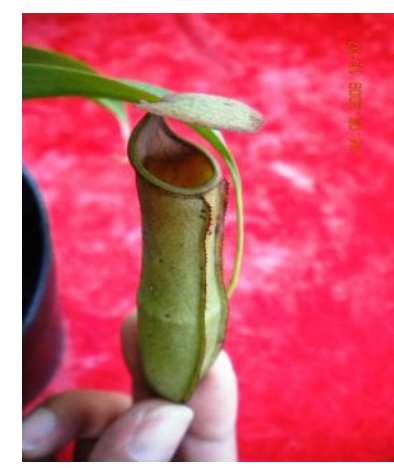

N. negleta

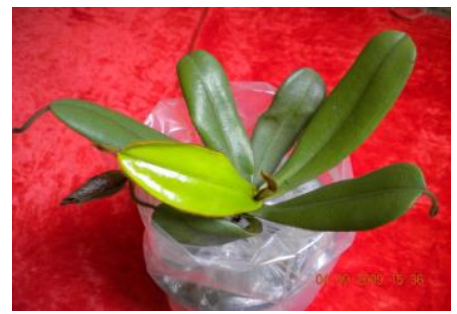

N. hirsuta

Gambar 1. Morfologi kantong dan daun Nepenthes spp. 
Tabel 1. Data morfologi daunh, batang, kantong, dan pembungaan dari lima Nepenthes spp. asal Kalimantan Barat

\begin{tabular}{|c|c|c|c|c|c|}
\hline \multirow{2}{*}{ No. } & \multirow{2}{*}{ Spesies } & \multicolumn{4}{|c|}{ Morfologi } \\
\hline & & Daun & Batang & Kantong & Perbungaan \\
\hline 1. & N. negleta & $\begin{array}{l}\text { Daun hanya memiliki helain } \\
\text { daun (melekat pada batang } \\
\text { atau duduk pada batang), } \\
\text { bangun } \\
\begin{array}{l}\text { lanceolatus/lancet, tepi daun } \\
\text { rata }\end{array}\end{array}$ & $\begin{array}{l}\text { Bulat licin, warna hijau } \\
\text { muda- coklat abu-abu } \\
\text { (tua) }\end{array}$ & & \\
\hline 2. & N. hirsuta & $\begin{array}{l}\text { Daun hanya memiliki helain } \\
\text { daun (melekat pada batang } \\
\text { atau duduk pada batang), } \\
\text { bangun } \\
\text { lanceolatus/lancet, ujung daun } \\
\text { membulat, permukaan bawah } \\
\text { daun berwarna coklat, tepi } \\
\text { daun rata dan berbulu }\end{array}$ & $\begin{array}{l}\text { Bulat licin dan berbulu, } \\
\text { warna hijau muda- } \\
\text { coklat abu-abu (tua). } \\
\text { Hampir seluruh } \\
\text { tanaman ditutupi oleh } \\
\text { bulu-bulu halus } \\
\text { berwarna coklat }\end{array}$ & $\begin{array}{l}\text { Kantong atas berbentuk } \\
\text { silinder berwarna kuning, } \\
\text { kantong bawah berbentuk } \\
\text { oval, memiliki dua sayap, } \\
\text { warna kantong putih } \\
\text { dengan lurik merah dan } \\
\text { penutup berbentuk oval } \\
\text { hingga bentuk jantung, taji } \\
\text { tidak bercabang }\end{array}$ & $\begin{array}{l}\text { Bentuk tandan, } \\
\text { panjang } \leq 25 \mathrm{~cm} \text {, } \\
\text { sepal lonjong, } \\
\text { panjang } \leq 4 \mathrm{~mm} \text {, } \\
\text { struktur } \\
\text { perbungaan betina } \\
\text { hampir sama } \\
\text { dengan jantan } \\
\text { tetapi ukurannya } \\
\text { lebih pendek }\end{array}$ \\
\hline 3. & $\begin{array}{c}N . \\
\text { bicalcarata }\end{array}$ & $\begin{array}{l}\text { Daun hanya memiliki helain } \\
\text { daun (melekat pada batang } \\
\text { atau duduk pada batang), } \\
\text { bangun daun bulat telur hingga } \\
\text { lanceolatus/lancet, ujung daun } \\
\text { muda membulat pada daun tua } \\
\text { ujung daun meruncing, } \\
\text { permukaan daun berbulu, tepi } \\
\text { daun rata dan berbulu, tulang } \\
\text { daun membulat }\end{array}$ & $\begin{array}{l}\text { bulat licin dan berbulu, } \\
\text { warna hijau muda- } \\
\text { coklat abu-abu (tua), } \\
\text { merambat }\end{array}$ & $\begin{array}{l}\text { Kantong berbentuk silider } \\
\text { tanpa sayap, memiliki dua } \\
\text { taring di bawah kantong } \\
\text { penutup }\end{array}$ & $\begin{array}{lr}\text { Bentuk malai, } \\
\text { panjang } \leq 100 \mathrm{~cm}, \\
\text { tanpa } \\
\text { pelindung, daun } \\
\text { berbentuk } \text { oepal } \\
\text { terbalik hingga } \\
\text { lanset, panjang } \leq \\
4 \mathrm{~cm}, \text { perbungaan } \\
\text { jantan r lebih } \\
\text { pendek daripada } \\
\text { betina }\end{array}$ \\
\hline 4. & N. veitchii & $\begin{array}{l}\text { Daun berupih, ujung daun } \\
\text { berbelah, permukaan daun } \\
\text { berbulu, bangun daun pasak } \\
\text { hingga lanceolatus/lancet }\end{array}$ & $\begin{array}{l}\text { bulat licin dan berbulu, } \\
\text { warna hijau muda- } \\
\text { coklat abu-abu (tua), } \\
\text { memanjat pada pohon }\end{array}$ & $\begin{array}{l}\text { Kantong bawah berbentuk } \\
\text { oval berwarna hijau atau } \\
\text { coklat dengan bibir yang } \\
\text { melebar berwarna merah, } \\
\text { mulut oval, penutup oval, } \\
\text { kantong atas ukurannya } \\
\text { lebih besar dari kantong } \\
\text { bawah }\end{array}$ & $\begin{array}{l}\text { Bentuk tandan, } \\
\text { panjang } \leq 40 \mathrm{~cm}, \\
\text { sepal berbentuk } \\
\text { bundar hingga } \\
\text { elip, panjang } \leq 4 \\
\text { cm }\end{array}$ \\
\hline 5. & N. clipeata & $\begin{array}{l}\text { Daun tebal dengan bangun } \\
\text { daun perisai, memiliki trikoma } \\
\text { pada permukaan bawah. Pada } \\
\text { daun muda yang masih } \\
\text { menggulung diselimuti trikoma }\end{array}$ & $\begin{array}{l}\text { Berbentuk silinder, } \\
\text { panjang, dengan } \\
\text { trikoma yang halus. }\end{array}$ & $\begin{array}{l}\text { Bentuk kantong pada } 1 / 3 \\
\text { bagian bawah berbentuk } \\
\text { bulat dan } 2 / 3 \text { bagian atas } \\
\text { berbentuk corong dengan } \\
\text { warna putih berlurik-lurik } \\
\text { merah, mulut bundar } \\
\text { dengan penutup berbentuk } \\
\text { oval hingga jantung }\end{array}$ & $\begin{array}{l}\text { Berbentuk tandan } \\
\text { yang panjang }(45 \\
\mathrm{cm})\end{array}$ \\
\hline
\end{tabular}

\section{Kajian Sitologi Sayatan Paradermal Daun Nepenthes spp.}

Pada sayatan paradermal daun, bentuk sel epidermis antara kelima spesies Nepenthes (N. veitchii, $N$. clipeata, $N$. bicalcarata, $N$. hirsuta, dan $N$. negleta) mempunyai bentuk yang hampir sama dan tersusun rapat (Gambar 2). Panjang dan lebar sel epidermis antara permukaan atas dan bawah memiliki ukuran yang berbeda, di mana permukaan bawah memiliki ukuran cenderung lebih panjang daripada permukaan atas. Ukuran panjang sel epidermis terpanjang dimiliki oleh sel $N$. bicalcarata diikuti oleh N. hirsuta (Tabel 2).

Pengamatan stomata pada sayatan paradermal daun memperlihatkan pada $N$. bicalcarata, N. veithii, $N$. hirsuta, dan $N$. clipeata bersifat daun epistomatik, yaitu stomata hanya terdapat pada permukaan bawah. Sedangkan $N$. negleta memiliki stomata pada permukaan atas dan bawah daun (daun amfistomatik) dengan jumlah stomata lebih banyak terdapat pada permukaan atas daun. Susunan stomata pada Nepenthes tersusun tersebar dengan bentuk ginjal. Menurut Hidayat (1995); Sutrian (1996), pada daun dengan sistem pertulangan menjala, stomata menyebar tidak teratur sedangkan pada daun dengan sistem pertulangan sejajar seperti pada Gramineae, stomata tersusun dalam barisan yang sejajar. Pada kebanyakan tumbuhan kecuali Gramineae dan Cyperaceae sel penjaga secara umum berbentuk ginjal. 
Ukuran stomata terpanjang dimiliki oleh $N$. bicalcarata dan ukuran stomata terpendek dimiliki $N$. hirsuta. Kerapatan stomata terbanyak dimiliki oleh $N$. negleta yaitu 272,83 stomata/ $\mathrm{mm}^{2}$ dengan indeks stomata $22.09 \%$ dan kerapatan stomata terkecil dimiliki oleh $N$. hirsuta dengan indeks 10,63\%. Pada N. negleta jumlah stomata pada permukaan atas daun lebih sedikit dari permukaan bawah hanya $0.83 \%$. Hasil yang sama diperoleh pada tanaman Triticum (Teare et al., 1971), tanaman Populus (Pallardy and Kozlowski, 1979), dan pisang autotetraploid (Hamill et al., 1992), permukaan atas daun memiliki kerapatan stomata jauh lebih sedikit dibandingkan permukaan bawah daun.

Ukuran panjang stomata dapat digunakan sebagai pembeda tingkat ploidi salah satunya pada tanaman pisang (Damayanti, 2007; Hamill et al.,1992; Griffiths et al., 1996), pada Brassica oleracea (Horak, 1972), tanaman buah kiwi (Przywara et al., 1988), pisang autotetraploid (Hamill et al., 1992), Acacia mearnsii (Beck et al., 2002), dan tanaman chamomile (Lozykowska, 2003) semakin panjang ukuran stomata semakin tinggi tingkat ploidinya. Kerapatan stomata juga berhubungan dengan tingkat ploidi (Vandenhout et al., 1995; Beck et al., 2002). Namun hal ini belum dapat dibuktikan pada tanaman Nepenthes, sehingga sangat perlu dilakukan penelitian untuk jumlah kromosom.

Berdasarkan jumlah dan letak sel tetangga, Nepenthes memiliki stomata tipe anomositik dan aktinositik (Gambar 2). N. bicalcarata memiliki tipe stomata aktinositik, yaitu memiliki stomata berbentuk ginjal dikelilingi oleh 4 sel tetangga atau lebih yang tersusun radier. Sedangkan empat spesies Nepenthes lain bertipe anomositik (bentuk sel tetangga sama dengan sel epidermis) dengan jumlah sel tetangga 4-6.

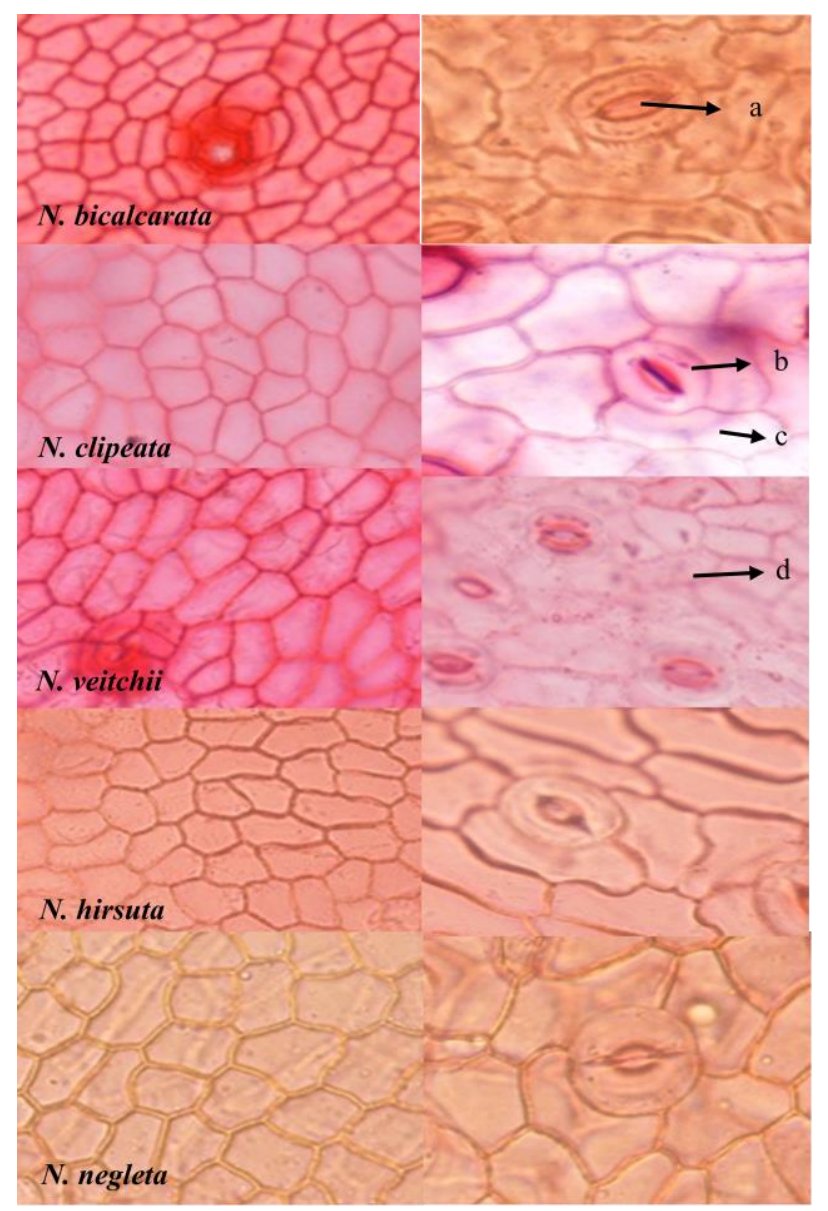

Gambar 2. Sayatan paradermal daun Nepenthes. N. bicalcarata bertipe stomata aktinositik sedangkan $N$. clipeata, N. veitchii, $N$. hirsuta, dan N. negleta bertipe stomata anomositik.a. celah stomata; b. sel penutup; c. sel tetangga; d. sel epidermis

Kajian Anatomi Transversal Daun Nepenthes spp.

Pada sayatan transversal daun (Gambar 3) terdiri satu lapis sel epidermis pada permukaan atas (adaksial) dan permukaan bawah (abaksial) dengan kutikula yang tipis. Tebal kutikula beragam dan perkembangannya dipengaruhi oleh lingkungan. Kutikula pada Nepenthes bersifat lilin yang mempunyai peranan untuk mengurangi penguapan. Di bawah epidermis terdapat 1-2 lapis hipoepidermis dengan ukuran sel yang lebih besar dari epidermis. Mesofil daun terdiferensiasi menjadi selapis parenkim palisade dan parenkim spons (bunga karang).

Pada Nepenthes, jaringan palisade/jaringan tiang terdapat pada permukaan atas dengan susunan yang tidak teratur dengan bentuk sel yang tidak beraturan tidak seperti tiang namun tersusun lebih rapat dari jaringan spons yang memiliki ruang antar sel yang luas. Nepenthes memiliki jaringan palisade 1-2 lapis di sebelah atas dan jaringan spons di sebelah bawah. Tipe mesofil seperti ini menurut Hidayat (1995) adalah tipe daun dorsiventral atau bifasial. Panjang jaringan palisade terpanjang adalah $N$. hirsuta, terlihat dari susunan jaringan palisade yang lebih 
teratur dan tersusun lebih dari 1 lapis serta bentuknya memanjang. Jaringan palisade telah terspesialisasi untuk kegiatan efisiensi fotosintesis terlihat dari banyaknya kloroplas yang menempel pada tepi dinding sel. Sedangan jaringan spons terlihat terdiri dari sel bercabang yang tidak beraturan bentuknya. Pada Gambar 3 terlihat $N$. veitchii merupakan daun yang kompak, sedangkan pada empat spesies lainnya merupakan daun dewasa terlihat dari semakin renggangnya sel-sel pada mesofil yang ditandai dengan ukuran rongga udara yang besar.

Hasil sayatan transversal, daun $N$. veitchii memiliki ketebalan daun lebih tebal dari pada spesies lainnya (Tabel 2). Berdasarkan letak sel-sel penutup terhadap permukaan epidermis, $N$. negleta memiliki tipe stomata yang menonjol di atas permukaan helian daun, sedangkan pada $N$. veitchii memiliki tipe stomata kriptopor, yaitu stomata letaknya tenggelam terhadap permukaan helaian daun (Gambar 3).

Nepenthes memiliki banyak trikoma terutama pada permukaan bawah daun yang disebut dengan rambut daun dan tunas muda. Diduga trikoma pada permukaan tunas muda berfungsi menghasilkan sekret yang akan menjaga tunas dari kekeringan. Menurut Hidayat (1995), trikoma pada tanaman Nepenthes termasuk trikoma sekresi/kelenjar.

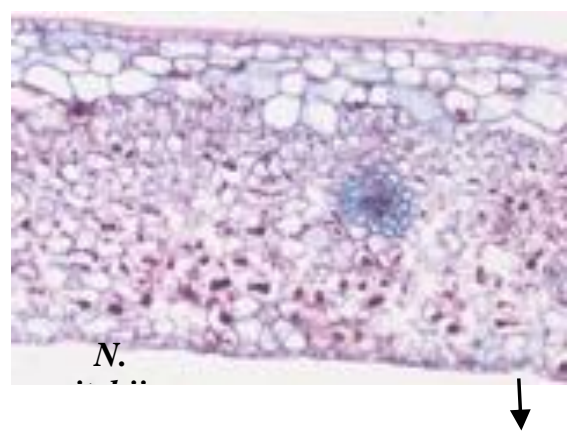

Mulut

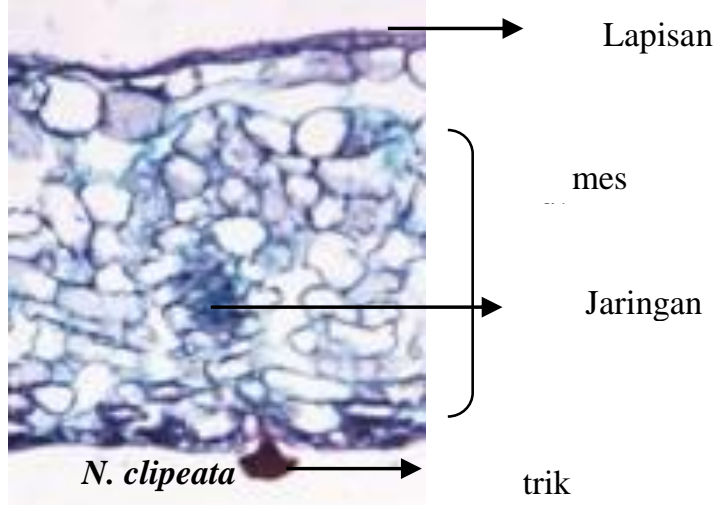

Epidermis

Jaringan

Jaringan

Rongga

Epidermis
N.

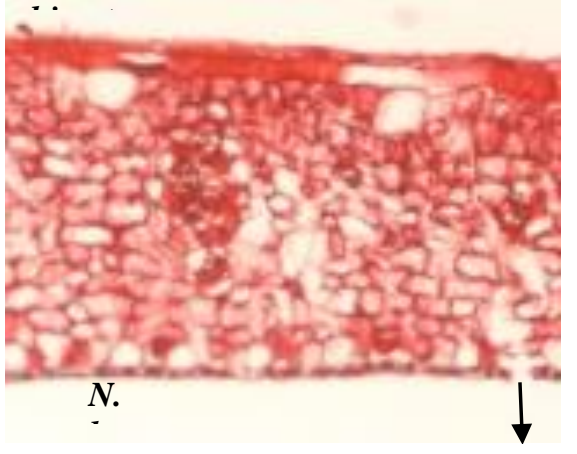

Mulut

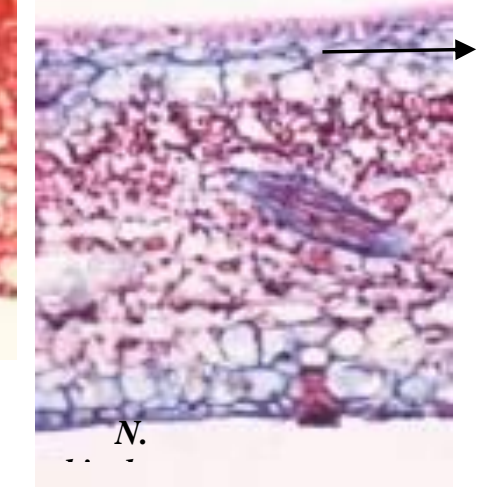

hipoepider

Gambar 3. Sayatan transversal daun Nepenthes. N. veitchii memiliki daun kompak. N. clipeata, hirsuta, N. negleta, dan N. bicalcarata merupakan daun dewasa dengan parenkim spons berisi ruang antar sel yang terlihat jelas. 
BIOEDUKASI 8(2): 5-11, Agustus 2015

Tabel 2 . Kisaran nilai dan nilai rerata peubah anatomi lima spesies Nepenthes spp. asal Kalimantan Barat

\begin{tabular}{|c|c|c|c|c|c|c|c|c|c|c|c|}
\hline \multirow{3}{*}{ No. } & \multirow{3}{*}{ Peubah Anatomi } & \multicolumn{10}{|c|}{ Spesies } \\
\hline & & \multicolumn{2}{|c|}{ N. clipeata } & \multicolumn{2}{|c|}{ N. veitchii } & \multicolumn{2}{|c|}{ N. bicalcarata } & \multicolumn{2}{|c|}{$N$. hirsuta } & \multicolumn{2}{|c|}{ N. negleta } \\
\hline & & Kisaran Nilai & $\begin{array}{c}\text { Nilai } \\
\text { Rerata }\end{array}$ & Kisaran Nilai & $\begin{array}{c}\text { Nilai } \\
\text { Rerata }\end{array}$ & $\begin{array}{c}\text { Kisaran } \\
\text { Nilai }\end{array}$ & $\begin{array}{c}\text { Nilai } \\
\text { Rerata }\end{array}$ & Kisaran Nilai & $\begin{array}{c}\text { Nilai } \\
\text { Rerata }\end{array}$ & $\begin{array}{c}\text { Kisaran } \\
\text { Nilai }\end{array}$ & $\begin{array}{c}\text { Nilai } \\
\text { Rerata }\end{array}$ \\
\hline 1. & $\begin{array}{l}\text { Panjang sel } \\
\text { apidermis atas } \\
(\mu \mathrm{m})\end{array}$ & $24,8-52,08$ & $37,2 \pm 4,77$ & $22,32-52,08$ & $32,73 \pm 4.18$ & $34,72-49,60$ & $40,67 \pm 2,89$ & $27,28-47,12$ & $38,69 \pm 3,29$ & $19,84-27,28$ & $23,81 \pm 1,26$ \\
\hline 2. & $\begin{array}{l}\text { Panjang sel } \\
\text { epidermis bawah } \\
(\mu \mathrm{m})\end{array}$ & $24,8-37,2$ & $29,76 \pm 2,83$ & $24,8-49,6$ & $34,22 \pm 4,60$ & $47,12-54,56$ & $49,10 \pm 1,44$ & $22,32-54,56$ & $40,67 \pm 5,41$ & $19,84-37,2$ & $29,26 \pm 3,18$ \\
\hline 3. & $\begin{array}{l}\text { Lebar sel } \\
\text { epidermis atas } \\
(\mu \mathrm{m})\end{array}$ & $14,88-32,24$ & $20,83 \pm 3,38$ & $17,36-24,8$ & $19,34 \pm 1,45$ & $12,4-19,84$ & $16,37 \pm 1,27$ & $14,88-24,80$ & $19,34 \pm 1,65$ & $9,92-12,4$ & $11,90 \pm 0,50$ \\
\hline 4. & $\begin{array}{l}\text { Lebar sel } \\
\text { epidermis bawah } \\
(\mu \mathrm{m})\end{array}$ & $12,4-17,36$ & $14,88 \pm 2,75$ & $14,88-19,84$ & $17,36 \pm 0,78$ & $12,4-17,36$ & $14,88 \pm 0,78$ & $14,88-19,84$ & $17,36 \pm 1,11$ & $9,92-14,88$ & $12,4 \pm 0,78$ \\
\hline 5. & $\begin{array}{l}\text { Panjang stomata } \\
\text { bawah }(\mu \mathrm{m})\end{array}$ & $29,76-37,2$ & $33,73 \pm 2,55$ & $29,76-34,72$ & $33,23 \pm 1,49$ & $34,72-39,68$ & $37,2 \pm 1,11$ & $27,28-29,76$ & $28,77 \pm 0,83$ & $29,76-32,24$ & $30,75 \pm 0,61$ \\
\hline 6. & $\begin{array}{l}\text { Lebar stomata } \\
\text { bawah }(\mu \mathrm{m})\end{array}$ & $19,84-24,80$ & $18,35 \pm 4,68$ & $19,84-27,28$ & $23,81 \pm 1,68$ & $14,88-19,84$ & $17,86 \pm 0,93$ & $24,80-27,28$ & $25,80 \pm 0,61$ & $17,36-22,32$ & $19,84 \pm 1,57$ \\
\hline 7. & $\begin{array}{l}\text { Panjang stomata } \\
\text { atas }(\mu \mathrm{m})\end{array}$ & - & - & - & - & - & - & - & - & $24,80-34,72$ & $29,76 \pm 1,57$ \\
\hline 8. & $\begin{array}{l}\text { Lebar stomata atas } \\
(\mu \mathrm{m})\end{array}$ & - & - & - & - & - & - & - & - & $24,80-29,76$ & $26,78 \pm 2,07$ \\
\hline 9. & $\begin{array}{l}\text { Kerapatan stomata } \\
\text { bawah }\left(\mathrm{jml} / \mathrm{mm}^{2}\right)\end{array}$ & $\begin{array}{l}150,29- \\
167,63\end{array}$ & 157,23 & $190,75-231,21$ & 205,78 & $\begin{array}{c}150,29- \\
179,19\end{array}$ & 168,79 & $132,95-150,29$ & 142,20 & $\begin{array}{l}196,53- \\
300,58\end{array}$ & 272,83 \\
\hline 10. & $\begin{array}{l}\text { Kerapatan stomata } \\
\text { atas }\left(\mathrm{jml} / \mathrm{mm}^{2}\right)\end{array}$ & - & - & - & - & - & - & - & - & $0-0,35$ & 0,24 \\
\hline 11. & $\begin{array}{l}\text { Indeks stomata } \\
\text { bawah }\end{array}$ & \multicolumn{2}{|c|}{$12,48 \%$} & \multicolumn{2}{|c|}{$19,47 \% \pm$} & \multicolumn{2}{|c|}{$15,11 \%$} & \multicolumn{2}{|c|}{$10,63 \%$} & \multicolumn{2}{|c|}{$22,09 \%$} \\
\hline 12. & $\begin{array}{l}\text { Indeks stomata } \\
\text { atas }\end{array}$ & \multicolumn{2}{|c|}{-} & \multicolumn{2}{|c|}{ - } & \multicolumn{2}{|c|}{-} & \multicolumn{2}{|c|}{-} & \multicolumn{2}{|c|}{$0,83 \%$} \\
\hline 13. & $\begin{array}{l}\text { Jumlah sel } \\
\text { tetangga }\end{array}$ & \multicolumn{2}{|c|}{4 sel tetangga } & \multicolumn{2}{|c|}{4 sel tetangga } & \multicolumn{2}{|c|}{ 4-5 sel tetangga } & \multicolumn{2}{|c|}{4 sel tetangga } & \multicolumn{2}{|c|}{ 4-6 sel tetangga } \\
\hline 14. & Tebal daun $(\mu \mathrm{m})$ & $\begin{array}{l}282,72- \\
312,48\end{array}$ & $300,58 \pm 5,62$ & $491,04-555,52$ & $512,86 \pm 19,17$ & $248-255,44$ & $249,98 \pm 2,65$ & $406,72-429,04$ & $410,19 \pm 7,38$ & $248-272,8$ & $257,92 \pm 6,02$ \\
\hline 15. & $\begin{array}{l}\text { Panjang jaringan } \\
\text { palisade }(\mu \mathrm{m})\end{array}$ & $52,08-57,04$ & $53,57 \pm 0,99$ & $44,64-59,52$ & $51,09 \pm 3,10$ & $44,64-54,56$ & $49,60 \pm 2,07$ & $49,60-62,00$ & $56,54 \pm 2,13$ & $24,8-37,2$ & $30,26 \pm 2,40$ \\
\hline
\end{tabular}




\section{KESIMPULAN}

Kelima spesies Nepenthes memiliki karakter morfologi yang beragam, dapat dilihat dari bentuk daun, batang, dan terutama bentuk kantong yang unik untuk setiap spesies. Hasil sitologi kelima spesies Nepenthes memperlihatkan tingkat keragaman antar spesies. $N$. bicalcarata memiliki panjang epidermis terpanjang dan ukuran stomata terpanjang dengan tipe stomata aktinositik. $N$ clipeata, $N$. veitchii, $N$. hirsuta, dan $N$. negleta memiliki tipe stomata anomositik. Stomata hanya terdapat pada permukaan bawah daun kecuali pada $N$. negleta terdapat juga pada permukaan atas daun. Kerapatan dan indeks stomata tertinggi dimiliki oleh $N$. negleta. Terdapat keragaman dalam jumlah sel tetangga yaitu berkisar 4-5 sel tetangga. Hasil sayatan transversal, terdapat keragaman pada mesofil (parenkim palisade dan parenkim spons). $N$. hirsuta memiliki susunan parenkim palisade yang lebih teratur. Jaringan epidermis tersusun atas satu lapis sel dengan jaringan hipodermis lebih dari satu lapis sel yang berukuran lebih besar. $N$. veitchii memiliki daun dengan ketebalan yang lebih tebal dan memiliki banyak trikoma.

\section{SARAN}

Perlu dilakukan kajian anatomi batang dan akar serta jumlah kromosom untuk melihat keragaman genetik pada tanaman Nepenthes.

\section{UCAPAN TERIMA KASIH}

Ucapkan terimakasih penulis sampaikan kepada Direktorat Jenderal Pendidikan Tinggi DP2M yang telah mendanai penelitian ini. Teruntuk khusus untuk Pak Ujang Hapid yang telah banyak membantu dalam penelitian ini.

\section{DAFTAR PUSTAKA}

Beck, S.L., Dunlop, R.W., \& Fossey, A. (2002). Stomatal length and frequency as a measure of ploidy level in black watlle, Acacia mearnsii (de Wild). Botanical Journal of the Linnear Society, 144(2), 177-181.
Damayanti, F. (2007). Analisis jumlah kromosom dan anatomi stomata pada beberapa plasma nutfah pisang (Musa sp) asal Kalimantan Timur. Biosientiae, 5, 1-12.

Griffiths, A.J.F., Miller, J.H., Suzuki, P.T., Lewondin, R.C., \& Gelbert, W.M. (1996). An Introduction to Genetic Analysis. Ed $6^{\text {th }}$. W. H. Freeman and company. New York.

Hamill, S.D., Smith, M.K., \& Dodd, W.A. (1992). In vitro induction of banana autotetraploids by colchicine treatment of micropropagated diploids. Aust. J. Bot, 40, 887-896.

Hidayat, E. B. (1995). Anatomi Tumbuhan Berbiji. Penerbit ITB. Bandung.

Horak, J. (1972). Ploidy chimeras in plants regenerated from the tissue cultures of Brassica oleracea L. Biologia Plantarum, $14(6), 423-426$.

Lozykoska, K.S. (2003). Determination of the ploidy level in chamomile (Chamomilla recutia (L.) Rausch.) stains rich in a-bisabolol. J. Appl. Gent, 44(2), 151-155.

Mansur, M. (2006). Nepenthes - Kantong Semar yang Unik. Penebar Swadaya. Jakarta.

Mansur, M., Damayanti, F., \& Roostika, I. (2009). Diversity of Nepenthes spp in West Kalimantan. JSPS International Training Program (ITP) and Ecological Society of Indonesia to Protect Diversity of Bioresources in the Tropical Area. Cibinong, 25-26 November.

Pallardy, S.G., \& Kozlowski, T.T. (1979). Frequency and length of stomata of 21 Populus clones. Can. J. Bot, 57(22), 25192523 .

Przywara, L., Pandey, K.K., \& Sanders, P.M. (1988). Length of stomata as an indicator of ploidy level in Actinidia deliciosa. New Zealand Journal of Botany, 26, 179-182.

Sass, J.E. (1951). Botanical Microtechnique. Ed. Ke2. The Iowa State Collage Press. Iowa.

Sutrian, Y. (1996). Pengantar Anatomi Tumbuh-Tumbuhan tentang Sel dan Jaringan. Rineka Cipta. Bandung.

Teare, I.D., Peterson, C.J., \& Law, A.G. (1971). Size and frequency of leaf stomata in cultivars of Triticum aestivum and other Triticum spesies. Crop. Sci, 11, 496-498.

Vandenhout, H., Ortiz, R., Vuylsteke, D., Swennen, R., \& Bai, K.V. (1995). Effect of ploidy on stomatal and other quantitative traits in plantain and banana hybrids. Euphytica, 83, 117-122. 